\title{
THE UNIFICATION OF PRIVATE MARITIME LAW BY INTERNATIONAL CONVENTIONS
}

\author{
A. N. YianNopoulos*
}

INTRODUCTION

Since ancient times, and until the emergence of modern national states, the law governing maritime commerce had been largely uniform in the western world. ${ }^{1}$ In the eighteenth and nineteenth centuries, however, legislative enactments and judicial practices in pursuit of narrowly conceived national interests gradually displaced in various countries the venerable and uniform "law of the sea"2 and gave rise to sharp conflicts of laws.

The movement of goods from country to country was thus hampered at a time when advancing technology and the spreading industrial revolution were about to lead to an expansion of maritime commerce on a world scale. Indeed, large scale international trade has always needed, in addition to other favorable conditions, a certain measure of security and predictability ${ }^{3}$ with respect to the enforcement of obligations. The diversity of commercial laws prevailing in various parts of the world, however, created an uncertainty as to the existence, size, and content of obligations. Interested parties could not readily ascertain the place where a potential dispute was to be settled, the governing substantive law, and whether a judgment obtained in one country could be enforced in another country.

Traditionally, a minimum of certainty has been secured in international commercial relations by resorting to conflict of laws rules. The function of these rules is to refer a given dispute to a definite legal system in accordance with a variety of contacts considered important for the legal relation in question. In commercial transactions the parties have always enjoyed a large measure of autonomy and thus they have been able, by selecting the appropriate contacts, to subject their relations to a desired legal system which eventually furnished the substantive rule of decision. ${ }^{4}$ While the conflicts method has several advantages, its drawbacks are

*LL.B. 1950, University of Thessaloniki; M.C.L. 1954, University of Chicago; LL.M. 1955, J.S.D. 1956, University of California, Berkeley; Dr.Jur. 1960, University of Cologne. Professor of Law, Louisiana State University. Author, Neglygence Clauses in OCEAN Bills of LAding (1962).

${ }^{1}$ See Grant Gilmore \& Charles L. Black, Jr., Admiralty 2-8 (1957); 3 John H. Wiomork, A PANORAMA OF the WorLd's Legal. SySTEMS 876-914 (x928).

${ }^{2}$ See Francesco Berlingieri, Verso l'unificazione del Dirutto der Mare 20 (1933); 3 Ernst Raber, Conflict of Laws: A Comparative Study 238 (2d ed. Bernstein, 1964).

${ }^{3}$ See 2 Ernst Raber, Conflict of Laws: A Comparative Study 367-70 (2d ed. Drobnig, 1960); id., Conflict Rules on Contracts, in SUMmer Institute of University of Michigan LAw Schoor, ConFLICT OF LAWS AND INTERNATIONAI CONTRACTS I27, I29 (1949).

"See, in general, McCartney, The Use of Choice-of-Law Clauses in International Commercial Contracts, 6 Whyne L. Rev. $34^{\circ}$ (1960); James, Autonomy of the Parties on Conflict of Laws Contracts, 36 Cen.-Kent L. Rev. 34 (1959); Levin, Party Autonomy: Choice-of-Law Clauses in Commercial Contracts, 46 GEO. L.J. 260 (1957); Neumayer, Autonomie de la volonté et dispositions impératives en droit international privé des obligations, [1957] Revue CritiQue de Droir International PruvE [hereinafter cited as REv. CR. Dr. INT'L PR.] 579; Yntema, "Autonomy" in Choice of Law, I AM. J. Comp. L. 34I (1952). 
apparent. Usually it presupposes a thorough familiarity with a number of legal systems, with regard to both substantive law and conflicts rules which may differ from country to country. Further, resort to choice of law is conducive to certainty only after the forum itself its known. ${ }^{5}$

Beginning with the last decades of the past century, it has become increasingly apparent that a higher measure of certainty and predictability could be achieved by making uniform, first, the conflicts rules, and then the substantive law prevailing in various parts of the world. ${ }^{8}$ While uniformity of law and decision can be achieved in several ways, ${ }^{7}$ adoption of international conventions incorporating the rules intended to become uniform in all of the contracting states has emerged as, perhaps, the most important method. ${ }^{8}$ The law of merchant shipping was, quite naturally, one of the first branches of private law to attract attention for possible unification. Actually, unification in this area was more than simply desirable; it was virtually

\footnotetext{
${ }^{5}$ See A. N. Yiannopotilos, Negligence Clauses in Ocean Bilis of Lading 12 (1962); Lemhöfer, Die Beschränkung der Rechtsvereinheitlichung auf Internationale Sachverhalte, [I960] RABELS ZEITSCHRIFT FŬR AUSLÂNDISCHES UND INTERNATIONALES PRIVATRECHT [hereinafter cited as RABELS Z.] 401, 405 (I960); Hamel, Perspectives ef limites de l'unification du droit privé, [195I] II L'UNIFIcation DU DROIT $6 \mathrm{x}, 65$.
}

- Sec Werner Scherrer, Zur Frage der internationalen Vereinheitzichung des Privatrechts I7 (1939); I EtienNe Bartin, Principes de dRoIt international PRIvE 74 (1930); Matteucci, Unification of Conficts Rules in Relation to International Unification of Private Law, in SUMMER INSTITUTE or University of Michigan LAW School, Conflict of Laws and International Contracts I50 (1949).

${ }^{2}$ See AdOLP F. SChNITZER, DE LA DIVERSTTE ET DE L'UNIFICATION DU DROIT 20-43 (I946); WERNER Scherrer, Zur Frage der internationalen Vereinheitlichung des Privatrechts 20-25 (I939); Batiffol, Conflict Avoidance in European Law, 21 LAw \& Contemp. Prob. 57I (I956); Lederman, Confict Avoidance by International Agreement, 2 I LAW \& CoNTEMP. ProB. 58I (1956); Metteucci, The Methods of the Unification of Law, [1956] L'Unification du Drorr 3; Pilotti, Les Méthodes de l'unification, [I956] L'Unification dU Droir 335.

'See Chauveau, Conventions for Uniform Laws, [1956] 83 Journal du Droit International [hereinafter cited as J. DR. INr'L] 571, 575; Demogue, L'unification international du droit privé, [1927] Revue Droit International [hereinafter cited as Rev. Dr. Int'L] 699, 722 (I927); Franck, $A$ New Law for the Seas, 42 L.Q. Rev. 25 (1926).

Quite apart from unification by international conventions which will be discussed in detail, a large measure of uniformity has been achieved in maritime commerce, as in international trade in general, by the use of standard forms of contract and general conditions formulated by various international agencies for the use of the business world. This form of unification has been termed "international commercial custom" and has been likened to the ancient law merchant. See Civiv M. Schmitthoff, The UnificaTION OF THE LAW OF INTERnAtional TRADE 7 (Gothenburg School of Economics and Business Administration Publication 27, 1964 ). Of general importance are the various practices formulated by the International Chamber of Commerce, and, particularly, the Incoterms, 1953, and the Uniform Customs and Practice for Documentary Credits, 1962 Revision. In the field of merchant shipping, uniformity has been promoted by the use of standard bills of lading and charter-parties of various Shipping Conferences which, in turn, incorporate practices formulated by international organizations. For example, most bill of Jading and charterparties incorporate the York-Antwerp Rules, 1950, on the adjustment of General Average. See Felde, General Average and the York-Antwerp Rules, 27 Tur. L. Rev. 406 (I953); Yancey, York-Antwerp Rules, 1950, 6 Loyola L. Rev. I2I (I952); Govare, Les règles d'York et d'Anvers 1950, [1950] Droit Maritime Français [hereinafter cited as D.M.F.] 3. In the light of these developments, the law of international trade may be described today as largely "clausal law." Sundberg, The Law of Contracts, jurisprudential Writing in Search of Principles, in 7 Scandinavian Studies IN Law I25 (1963).

Further, a large measure of uniformity has been achieved by the incorporation into national legislations of rules copied from foreign codes, international custom, or international conventions. For a survey of this form of unification, see Rodière, Codes maritimes nouveaux et projets de codes maritimes, in ETudes juRIDiques ofFertes ì Leon Julliot de LA Morandière 471 (x964). 
necessary because of the great importance of maritime transportation for the economy of several countries which suffered the repercussions of the then existing conflicts among maritime laws.

Until about the end of the last century, the movement for the unification of the law of merchant shipping had been, almost exclusively, the concern of the International Law Association, ${ }^{9}$ a non-governmental international organization with headquarters in London and branches throughout the world. In I896, however, the International Law Association realized that the volume of work in relation to maritime law and shipping had assumed such proportions as to justify the setting up of a separate organization to concern itself with the complicated problems of merchant shipping. This was the origin of the Comite Maritime International ${ }^{10}$ which was founded in Antwerp in 1897 by a jurist, an insurer, and a politician, with the cooperation of the International Law Association.

Today, the Comite Maritime International is the only international organization dedicated exclusively ${ }^{11}$ to the unification of private $^{12}$ maritime $^{13}$ law on a global

- See Nagendra Singh, International Conventions of Merchant Shipping 2273 (1963). Credit is due to the International Law Association for the formulation of the York-Antwerp Rules, 1890, on General Average, the Hague Rules, 1921, on Bills of Lading, and the Warsaw-Oxford Rules, 1932, for C.I.F. contracts, revised in collaboration with the International Chamber of Commerce.

${ }^{10}$ See Franck, $A$ New Law of the Seas, 42 L.Q. REv. 25 (1926). See also Chauveau, Liunification du droit maritime et le C.M.I., [1963] RevUe TrIMESTRIELle DE DRoIr Commercial [hereinafter cited as Rev. Trim. Dr. Consu.] 737; Sandiford, Note suo le rôle et les méthodes du Comité Maritime International en matière d'unification du drost maritime, [1956] L'Unificarion DU Droir 243; Scott \& Miller, Unification of Maritime and Commercial Law Through the Comite Maritime International, 1 INT'L L.Q. 482 (1947).

${ }^{12}$ Quite apart from the Comité Maritime International, a number of international organizations concern themselves with the unification of the law of international trade on a regional or global scale and thus they may, incidentally, deal with problems of unification of maritime law. In that regard, special mention deserve the activities of the United Nations Commission for Europe and of the Rome Institute for the Unification of Private Law. See Clive M. Schmitthoff, The Unipication of the Law of International Trade 16 (Gothenburg School of Economics and Business Administration Publication 27,1964 ).

23 The term "maritime law" in a broad sense includes institutions of public international law, administrative law, labor law, social legislation, as well as institutions of strictly commercial (private) law. Activities for the unification of these various branches of maritime law in a broad sense have resulted in a large number of international treaties and conventions.

In the field of public international law, a number of conventions have been adopted dealing especially with Territorial Sea, Contiguous Zone, High Seas, International Straights and Canals, Landlocked States, Ports, Freedom of Transit, and the Regime of Navigable Watcrways. Sce, in general, C. J. Colombos, International LAw of THE SEA (5th ed. I962). For the text of the various conventions, see Nagendra Singh, International Conventions op Merchant Shippino 1139-1236 (1963).

In the field of administrative law, a large number of conventions have been adopted dealing cspecially with navigation, buoyage lighting of coasts, load lines, safety of life at sea, submarine cables and communications, tonnage measurement, and sanitation. For the text of these conventions, see Sincr, op. cit. supra, at 3-871.

Finally, in the field of labor law and social legislation special mention deserve the various maritime conventions and recommendations adopted by the International Labor Organization, dealing with such matters as employment of seamen, certificates of qualification and identity of documents, wages, hours of work, manning, social security, welfare of seafarers aboard ships and in ports, health of seamen, and prevention of accidents. For the text of these documents, see Sincr, op. cit. stipra, at 877-1040. Cf. Jambu-Merlin, Réflexions sur le droit social maritime, [196r] D.M.F. I31 (196I).

${ }^{18}$ Maritime law in a broad sense includes also the law of inland shipping. The various conventions adopted by the Brussels Diplomatic Conference, however, apply mostly to "sea-going" vessels. The 
scale. ${ }^{14}$ The membership of the Comité consists of individuals and National Associations of Maritime Law. The organization is strictly non-governmental in character, representing private initiative and expertise. Its main object is to further by conferences and "by publications and divers works"15 the unification of maritime law. The composition of the Comité is predominantly commercial; its lawyermembers serve primarily as advisers. Both the initial choice of the branch of maritime law to be unified and the final resolutions of the Comite are matters for the decision of the representatives of commercial and maritime interests in ship and cargo, such as underwriters, shipowners, average adjusters, and bankers, who are actually in control of the organization.

Projects for the unification of maritime law sponsored by the Comité go through several stages of evolution. First, a branch of maritime law is selected for possible unification and questionnaires are dispatched by the central office to the various national associations for the purpose of securing information concerning the state of the law in each country. Subsequently, the national reports are discussed at an international conference of the organization, and agreement is ordinarily reached as to the best rules suitable for general adoption. Then, the permanent office at Antwerp puts the agreed rules into the form of a convention and circulates the draft for consideration and report by all the national associations. Finally, an amended and approved draft convention is sent to the Belgian Government, with a request

unification of the law of inland shipping actually involves distinct problems and has been accomplished mostly on a regional basis. See Hostie, The Unification of European River Law, [1955] L'UNification DU Droit 77 .

14 There has never been a central international machinery, whether governmental or non-governmental, to control and regulate sea-transport on a world-wide basis. The Convention of the Inter-governmental Maritime Consultative Organization (IMCO) came into force in 1958 but, unlike the International Telecommunications Union or the International Civil Aviation Organization, the IMCO has been concentrating on purely technical and safety aspects of sea-transport. The IMCO has not attempted to regulate the economic, commercial, or operational aspects of sea-transport which, according to reservations made by member-states, should not be the concern of the organization. A number of other regional or global inter-governmental agencies, however, are concerned with certain aspects of the shipping industry within the arcas of their competence, as the International Telecommunications Union, the International Labour Organization and the Joint Maritime Commission, the Pan-American Union, and the Commonwealth Shipping Committee.

There are also several international organizations of a non-governmental character which, in some respects, are connected with merchant shipping. An attempt to list all would be purposeless. Organizations which have been granted consultative status by the IMCO deserve special mention. They are: the International Chamber of Commerce, International Organization for Standardization, International Union of Official Travel Organizations, International Shipping Federation, International Electrotechnical Commission, International Union of Marine Insurance, International Chamber of Commerce, International Confederations of Free Trade Unions, International Association of Lighthouse Authorities, and International Radio-Maritime Committee.

The unification of maritime law on a regional basis has made great progress in recent years. Of particular importance is the Scandinavian experience. See Ekeberg, The Scandinavian Co-operation in the Field of Legislation, [1948] L'UnIFICATION DU DRorT $32 x$ and annual reports in subsequent volumes of the same series. In countries of the Common Market, a determined effort has been made to harmonize the commercial law in general. And in Latin America, attention is due to the Treaty on International Commercial Navigation Law, Montevideo, 1940. A measure of unification on a regional basis has been also accomplished by bilateral treaties. See 2 A. N. Makarov, Quellen des internationalen PrivaTRECHTS 324-62 ( 1960$)$.

${ }^{18}$ Nagendra Singh, International Conventions of Merchant Shipping 1274 (I963). 
that it might convene a Diplomatic Conference at Brussels to consider it as an International Convention with such amendments as the Conference might think proper. The first Diplomatic Conference was convened by the Belgian Government in 1905 and the last one in 1962. In its eleven sessions, the Brussels Conference has adopted thirteen Conventions.

The unification of maritime law by international conventions involves the same theoretical and practical problems as the unification of law in general. ${ }^{16}$ Questions thus arise as to the desirability and limits of unification, ${ }^{17}$ methods and procedures for the achievement of formal and substantive uniformity, ${ }^{18}$ and the preservation of uniformity, once unification is achieved. ${ }^{10}$ These questions have been dealt with elsewhere in this symposium. This paper is limited to a survey of the progress of unification of private maritime law ${ }^{20}$ by international conventions drafted by the

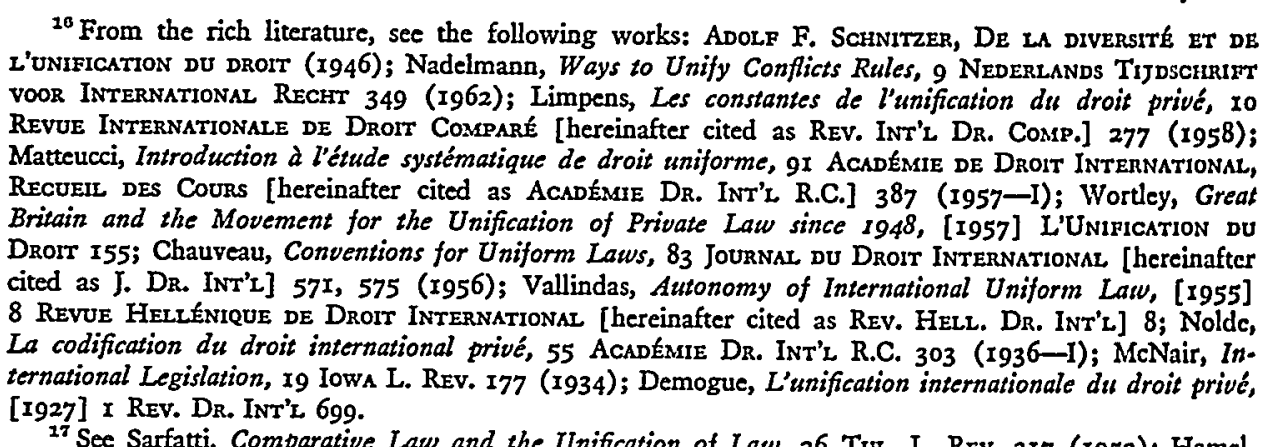

${ }^{17}$ See Sarfatti, Comparative Law and the Unification of Law, 26 TuL. L. REv. 317 (1952); Hamcl, Perspectives et limites de l'unification du droit prive, [1951] II L'UnIfICATION DU Droir 6r.

${ }^{18}$ See Nadelmann \& Reese, The American Proposal at the Hague Conference on Private International Law to Use the Method of Uniform Laws, 7 AM. J. Comp. L. 239 (r958); Matteucci, The Methods of the Unification of Law, [r956] II L'Unification DU Droit 2; Hamel, The Geneva Conventions on Negotiable Instruments and Methods of Unifying Private Law, [1948] L'UNification Du Droir 271; Gutteridge, The Technique of the Unification of Private Law, 20 BRIT. YB. INT'L L. 37 (1939).

${ }^{20}$ See Dehaussy, The Conditions of Application of Conventional Norms in the French Forum, $87 \mathrm{~J}$. DR. INT'L 703 (1960); Morse, Schools of Approach to the Interpretation of Treaties, 9 Catholic U.L. Rev. 36 (1960); Malintoppi, Mesures tendant à prévenir les divergences dans l'interprétation des rigles de droit uniforme, [1959] L'UnIFICATION DU DRort 249; Bentivoglio, Uniform Private Lasv and Uniformity of Interpretation, [I955] L'UNIFICATION DU DRoIT I27; Bayer, Auslegung thd Ergänztıng international vereinheitlichter Normen durch staatliche Gerichte, 20 RABELs Z. 603 (I955); Benoist, L'Interprétation des traités d'après la jurisprudence française, [1953] REv. HeLl. DR. INT'L I03; Mann, The Interpretation of Uniform Statutes, 62 L.Q. REv. 278 (1946); PETros G. VAlLINDAs, UNIForMity op INTERPRETATION of Conventions Rezating to Private International Law (1932) (in Greek).

${ }^{\circ}$ On the unification of maritime law, see, in general, ANTonio Malintoppi, Diritro uniforme $E$ Dirttro internazionale pRivato in tema di trasporto (1955); Francesco Berlingieri, Verso L'Unificazione del diRitto del Mare (1933); DE la Plesse, Le problèMe de l'unipication interNATIONALE dU dRoIT commerciale Maritime (Diss. Bordeaux, r932); Frederic Sohr, Le droit Maritime et son tnification internationale (IgI4); Arriu, L'unification du Droit maritime (Diss. Toulouse, 19r3); Standard, Maritime Conventions and World Peace through Law, I INTER-AMr. L. REv. 387 (1959); Mann, Reflections on a Commercial Law of Nations, 33 BRIT. YB. INT'L L. 20 (I957); Wüstendörfer, Leistungen und Grenzen der internationalen Vereinheitlichung des Seerechts, [1951] MONATsschrift pün Deutsches RECHT [hereinafter cited as M.D.R.] 449; Ripert, Les procédés de l'unification internationale du droit maritime, [I950] RrvisTA DI DiRirto DELla Navigazione [hereinafter cited as Riv. DiR. Nav.] 265; Bagge, International Unification of Commercial Law, [1948] L'UNipication DU Droir 253; Colombos, The Unification of Maritime International Law in Time of Peace, 21 BRIT. Yв. INT'L L. 96 (1944); Diena, Principes du droit international privé maritime, 5I AcadEMIE DR. INT'L R.C. 409 (I935I); Gutteridge, The Unification of the Law of the Sea, I6 J. CoMp. LEG. \& INT'L L. 246 (1934); Bon- 
Comite Maritime International and adopted by the Brussels Diplomatic Conference. Analysis of the substantive provisions of these conventions will be preceded by a brief discussion of a number of general questions raised especially by conventions for uniform maritime law.

\section{I}

\section{Observations in Generai}

Conventions for uniform maritime law, representing a relatively new development in the field of international relations, involve many complex issues which cannot always be resolved with certainty. For the purpose of the following discussion, relevant issues are only those concerning the binding force of international conventions on contracting states, courts, and individuals; the juridical nature of the rules contained in international conventions; the problem of the intended scope of unification; and the impact of mandatory conventional rules on the autonomy of the parties.

\section{A. Binding Force}

International conventions for uniform maritime law produce effects which should be measured in the light of both public international law and the internal law of the various contracting states. These conventions function at two distinct levels and much of the confusion in legal literature may be attributed to the fact that distinction between international and internal effects is not always made. ${ }^{21}$

It is a well-established proposition of international law that properly concluded and ratified conventions for uniform law create an international obligation for the contracting states to give effect to the rules agreed on as rules of law within their territories; and, in case this obligation is not properly discharged, international responsibility may attach. ${ }^{22}$ The specific content of this international obligation ordinarily depends on the provisions of the convention itself.

Thus, conventions for uniform maritime law quite frequently contain provisions concerning the method to be followed by the contracting states in giving effect to the rules adopted therein. The uniform rules may be appended in a schedule, with an attendant obligation that they will be given effect in the form adopted, or provision may be made for their incorporation in a form appropriate to the national

necase, Droit maritime international et droit maritime universel, [I932] Revue de Droit Maritime Compart [hereinafter cited as Rev. DR. Mar. COMP.] I; Demey, Le droit international privé maritime, [I927] Revue Generale de Droit et de la JuRisprudence [hereinafter cited as Rev. GeN. Dr. et JUR.] 37, 98; Franck, A New Law for the Seas, 42 L.Q. Rev. 25 (1926); Ripert, L'Unification du droit maritime, 50 J. DR. INT'x 209 (1923); Sieveking, Internationale Bestrebungen zur Vereinheitlichung des Seerechts, [I92I] Hanseatische REchts-Zeirschrift [hereinafter cited as Hans. R.Z.] 945.

${ }^{21}$ See Riesenfeld, The Power of Congress and the President in International Relations: Three Recent Supreme Court Decisions, 25 Carif. L. Rev. 643, 648 (1937).

32 See Alfred Verdross, Völkerrecht I27 (4th ed. I959); Charles Roussend, Droit international, PUBLIC APPROFONDI 56 (I96I); WesLey L. GOULD, AN INTRODUCTION tO INTERNATIONAL LAW 332 (I957); I Paul Guggenheim, Traite de droit international public 3 I (I953); I Oppenheim, INTERNATIONAL LAW 917, 337, 339 (8th ed. Lauterpacht I955). 
legislation of the contracting states. Further, provision may be made with regard to the scope of unification and the area of application of the uniform rules. In all these cases the contracting states undertake an international obligation, which may be express or implied, to comply with the convention. In case no such provision is made, a proper interpretation of the convention in the light of international practice might furnish conclusions with regard to the scope of the obligations assumed by the contracting states. ${ }^{23}$

Ordinarily, international conventions also contain provisions setting out the requirements for their becoming effective and binding upon the contracting countries. A usual provision to that effect is one declaring that the convention will become effective after a certain period of time following the deposition of a stated number of ratifications. In the absence of such provision or other indication, it seems that conventions become binding on the contracting states upon their individual exchange of ratifications. ${ }^{24}$

At this point, the question may be raised whether international conventions for uniform maritime law become binding on courts and individuals in the contracting states by virtue of ratification and by direct operation of international law. The question is necessarily connected with the broader issue of the relation between international and domestic law. And it is precisely in this field that a controversy is raging among scholars of international law. According to the so-called monistic doctrine, international law (both customary and conventional) is applicable in national courts "as such" and by its own force. ${ }^{25}$ On the other hand, according to the prevailing so-called dualistic doctrine, international law is applicable in national courts only by virtue of a constitutional, statutory, or customary rule of domestic law. ${ }^{28}$ Thus, international law becomes applicable only after its "transformation" by virtue of a domestic rule of incorporation.

The juridical nature of conventions for uniform maritime law is controversial, ${ }^{27}$ According to the prevailing view among scholars, the substantive articles of such conventions do not establish rules of international law. But even if that were

\footnotetext{
${ }^{23}$ See A. N. Yuannopoulos, Negligence Clauses in Bills of Lading 15 (1962).

84 Ratification is usually a voluntary state act; by signing an international convention a state does not assume by implication the obligation to ratify the same. Only in exceptional cases and in accordance with an express intention of the contracting states is the customary requirement of ratification waived. In such a case, a convention may produce its international effects and become binding on the contracting states upon the realization of any attached condition, without the need of ratification. See I Geore ScrwwrzzNBERGer, InTERnational Law 435-37 (3d ed. T957).

${ }^{25}$ See Hans Kelsen, Principles of International Law 403-04 (1952); id., Théorie générale du droir international public, 42 ACAdÉmIE DR. INT'x R.C. II9 (1932-IV); ALFREd Verdross, VöLkenReCHT 60-7I (4th ed. 1959).

${ }^{28}$ See Heintich Trueper, VöLKerrecht und LaNdescrecht (1899); id., Les rapports entre le droit interne et le droit international, I AcADEMIE DR. INT's R.C. 77-12I (1923); I Dionisio Anzilotri, Corso Di Diritto internazionale 49-63 (1955); G. A. Walz, VölKerRecht UND staAtLiches Recht (1933); id., Les rapports du droit international et du droit interne, 6r ACADEMIE DR. INT'L R.C. $379-456$ (1937III).

${ }^{27}$ See text infra at notes $35-37$.
} 
the case, it could be concluded on the basis of the prevailing doctrine in international law that conventions for uniform law are not as such applicable to private relations; courts and individuals are bound only by national laws; and conventions become binding on them only in so far as they have been transformed into domestic law by virtue of some domestic rule. ${ }^{28}$

As international conventions are not ordinarily binding on courts and individuals in the contracting states by virtue of international law, their internal effects necessarily depend on the law of each state. Ordinarily, constitutional provisions establish the procedures whereby conventions may become part of the law of the land.

According to some constitutions, properly signed and ratified international conventions are part of the law of the land. ${ }^{29}$ Judicial practice and doctrine, however, tend to construe such provisions narrowly and distinction is ordinarily drawn between self-executing conventions and conventions which require additional legislation. The former are rendered directly applicable in national courts by mere ratification as soon as they become internationally effective; the latter are given the force of law in the domestic sphere by virtue of implementing legislation. The problem thus arises as to which conventions are self-executing. The answer ordinarily depends on constitutional interpretation and on the intention of the contracting states, namely, whether an agreement was made which, by its terms, was to operate directly on private relations or through the enactment of appropriate legislation. ${ }^{30}$

Other constitutions, however, provide that conventions, without distinction, are rendered applicable in internal courts only after their execution by special statute or ordinance, or even after their enactment into law in accordance with the usual legislative procedures involved in all law-making. Most constitutions follow this approach and require implementing action in all cases, though several differences are displayed with regard to the particular method whereby conventions become part of the law of the land. ${ }^{31}$ Ratification (effected by the executive branch of the government with or without the legislature's authorization or consent, as prescribed by each country's constitutional law and custom) is still a necessary prerequisite for the international validity of the convention. In turn, the international validity of

\footnotetext{
${ }^{28}$ However, it should be noted that in recent international practice exceptions are known whereby conventions may become binding on courts and individuals by direct operation of international law; such exceptions are ordinarily based on an express undertaking by the contracting states. See I Georg DAHM, VölKERRECHT 53-69, 4II-I9 (I958).

${ }^{30}$ See, e.g., U.S. Const. art. VI(2); cf. Swiss Const. art. II3; Austrian Const. arts. 9, $49(\mathrm{I})$. Constitutional provisions may be found in U.N. Leg. Ser. No. 3 and in Amos J. PeasleE, Constrturtons of Nations I-III (2d ed. I956).

${ }^{30}$ Cf. Foster v. Neilson, 27 U.S. (2 Pet.) 253, 3I4 (1829); West German Supreme Court, June 2I, 1955, 18 B.G.H.Z. 22, 26.

${ }^{32}$ For a comparative survey, see I Georg Dam,, Völkerrecht 57-68 (I958); Oliver, Historical Development of International Law; Contemporary Problems of Treaty Law, 88 AcabEMIE DR. INT'L R.C. 42 (1955-II). See also Seidl-Hohenveldern, Relations of International Law to Internal Law in Austria, 49 AM. J. INT'z L. 451, 460 (1955); Münch, Droit international et droit interne d'après la Constitution de Bonn, [1950] Revue internationale Françatse do Drott des Gens [hereinafter cited as Rev. Int'L DR. GeNs] 5; Mann, The Interpretation of Uniform Statutes, 62 L.Q. REv. 278 (1946).
} 
the convention may (under domestic law) be a prerequisite for the application of the convention in national courts. ${ }^{32}$

\section{B. The Juridical Nature of Conventions for Uniform Law}

The juridical nature of international conventions for uniform maritime law has been a controversial subject. ${ }^{33}$ These conventions contain two distinct sets of provisions: (I) the rules which are intended to become uniform in all contracting states, and (2) the provisions defining the international obligations assumed by the contracting states among themselves. The usual provisions relating to the international validity of the convention, its possible revision, and those concerning subsequent adherences belong to the latter category. With regard to the juridical nature of such provisions, there is not much disagreement: they are treaty provisions functioning within the framework of international law and constituting a lex inter partes. ${ }^{34}$

There is no agreement, however, with regard to the juridical nature of the rules which are intended to become uniform in all contracting states. Such rules are regarded as "international legislation," 35 as a "model"36 for domestic legislation, or as a category by themselves. ${ }^{37}$ The issue has practical significance from the viewpoints of both international and internal law. ${ }^{38}$ According to the better view, conventions for uniform maritime law have two aspects, one international and the other domestic. $^{39}$ The international aspect is that conventions for uniform maritime law regulate relations among sovereigns, as they contain an international obligation to enact legislation in conformity with the convention and in the origin and function of the uniform rules. The domestic aspect is that the uniform rules are primarily intended to regulate relations of private individuals and that the method of incorporation is ordinarily determined by domestic rather than international law.

Consequently, while the provisions defining the scope of the obligations assumed belong to the sphere of international law, the rules intended to become uniform are neither international legislation nor merely model for domestic legislation. They are not international legislation because the plenipotentiaries of the contracting

${ }^{82}$ See Dehaussy, The Conditions of Application of Conventional Norms in the French Forum, [1960] J. DR. INT'I 703 (I960).

${ }^{38} \mathrm{Sec}$ A. N. Yiannopoulos, Negligence Clauuses in Ocean Bills of Lading ig (1962).

84 See I Georg SChWARzenberger, International Law 446-7I (3d ed. 1957).

${ }^{86}$ See LoUIS DE NAURoIs, LES tratTÉs inTERNATIONAUX DEVANT LES JURISDICTIONS NATIONALES 55 (I934); 2 Georges Scelle, PrECTS DE DROIT DEs GENs 526-46 (1934); Chauveau, Conventions for Uniform Laws, [1956] J. DR. INT'L 571, 575.

${ }^{38}$ See Arnold W. Knatth, The American LaW of Bills of Lading 154 (4th ed. 1953); I Georoes Ripert, Droit Marttime 72 (4th ed. I950); Georges Maras, Les transports internationauX dis MARCHANDISES PAR MER ET IA JURISPRUDENCE EN DROIT COMPARE I8, I03 (I949).

${ }^{87}$ See C. WiLfRed Jenks, The Common Law of Mankind 5 I (1958); I Oppenheim, International LAw 894 (8th ed. Lauterpacht, I955); Bayer, Auslegung und Ergänzzing international vereinheitlichter Normen durch staatliche Gerlichte, 20 RABELS Z. 603, 629 (1955).

${ }^{38}$ See A. N. Yinnnopoulos, Negligence Clauses in Bilis op Lading $20-23$ (1962).

${ }^{30}$ See note 37 supra. 
states do not constitute a legislative organ of the international community and because international law ordinarily regulates only relations among sovereigns. Also, the uniform rules are not merely a model for domestic legislation because, according to some constitutions, effect may be given to them by ratification alone or by special statutes and ordinances without resorting to ordinary legislative procedures. After their incorporation, one way or another, into the several legal systems, the interpretation of the uniform rules may be controlled by international rather than domestic law. This approach, placing emphasis on the distinctly dual character of conventions for uniform law and claiming autonomy for "international uniform law," ${ }^{40}$ offers several advantages: it leaves room for harmless differences of opinion with regard to the juridical nature of conventions for uniform law, explains sufficiently the differences in legislative and judicial practices prevailing in various parts of the world, and may result eventually in an expansion of unification to the advantage of international relations.

\section{The Scope of Unification}

From the viewpoint of intended uniformity and the impact on problems of conflict of laws, international conventions for uniform law may be distinguished into two categories: (I) those designed to suppress conflicts of substantive or choice-of-law rules by making such rules uniform in all of the contracting states, and (2) those designed not only to suppress existing conflicts but also to eliminate completely the necessity of resorting to choice-of-law rules by introducing uniform legislation applicable to international relations or to both domestic and international relations. ${ }^{41}$

All conventions for the unification of private maritime law belong to the second category. With respect to the subject matter covered by the various conventions, choice of law becomes unnecessary among contracting states, whether the uniform legislation applies to international relations only or to both international and domestic relations.

In the first instance, each country applies the same substantive rules of law as a modern "jus gentium" to all cases having the specified international contacts. ${ }^{42}$ Under such circumstances there is a juxtaposition between rules adopted in the convention and the domestic regulations of the contracting states which may have a different content. ${ }^{43}$ However, each country, though not under international

${ }^{0}$ Vallindas, Autonomy of International Uniform Law, [1955] Rev. HeLL. DR. INT'L 8.

${ }^{1}$ On the classification of conventions for uniform law, see A. N. Yisnnopoulos, Negligence Clauses IN BILIS OF LADING 23-28 (I962).

${ }^{2}$ Matteucci, The Methods of the Unification of Law, [1956] L'Unification Du Droit 3, 35.

${ }^{4}$ This method was followed, for example, in the Collision Convention of rgro. See text infra, at note 50. Unification of law with regard to international relations alone has the additional advantage of allowing drafting committees freedom to adopt the best possible rules without following slavishly the pattern of a number of national laws; adoption of such conventions by a large number of states is facilitated by the fact that the supremacy of the national law in the domestic sphere remains intact. The criteria adopted for the definition of "international" relations frequently vary with the subject matter of 
obligation, may extend the application of the uniform rules to domestic relations. Indeed, the retention of two distinct bodies of law within the same jurisdiction may give rise to difficult questions of delimitation of their respective areas of application and may result in unequal administration of justice. ${ }^{44}$

In the second instance, each state applies the same substantive rules of law whether the relations involve exclusively domestic or international contacts. ${ }^{45}$ As in the preceding instance, there is no room for the application of a definite national law; and even further, the nationality of the parties and all other traditional contacts utilized to designate a transaction as international become irrelevant. The uniform rules apply to the specified relations either as law of the forum or as treaty law.

\section{Mandatory Rules and Party Autonomy}

In commercial transactions, the parties ordinarily enjoy a large measure of freedom to shape their relations as they desire. In addition to this autonomy under substantive law, the parties to commercial transactions enjoy a similarly large measure of autonomy in the field of conflict of laws, i.e., freedom to select their forum and the law governing their relations. ${ }^{46}$

In contrast with these broadly accepted principles of contractual freedom under the internal law of various countries, conventions for uniform maritime law ordinarily introduce "mandatory" rules which render all contrary agreements without effect. The main theoretical and practical problem in that regard is to what extent the uniform rules exclude the autonomy of the parties under the domestic legal order.

When a legal relation is governed by the uniform rules as enacted in the forum, contractual provisions in direct conflict with mandatory rules of the convention are quite naturally disregarded. Questions arise, however, as to whether the application of the convention may be avoided by choice of foreign law or by jurisdictional agreements for the settlement of disputes abroad. As a rule, courts in various countries, either by resorting to notions of public policy or by considering the convention applicable as a matter of law and as excluding autonomy with respect to choice of law or of forum do not permit this avoidance. ${ }^{47}$

A different problem arises when contractual clauses violate, whether directly or indirectly, the uniform rules as enacted in a foreign jurisdiction. Assuming that

a convention. Thus differences of nationality of the parties to a contract, their domicile or place of business in different countries, and carriage of goods or persons from country to country have been relied upon in various conventions for the characterization of legal relations as "international."

is See I Georges Ripert, Droit Maritime 72 (4th ed. 1950).

${ }^{20}$ This was, for example, the scope of unification contemplated by the Bills of Lading Convention.

See A. N. Yiannopoulos, Negligence Clauses in Bills of Lading 43 (1962).

${ }^{18}$ See text at note 4 supra.

${ }^{17}$ For a survey of national practices, see A. N. Yiannopouros, Negligence Clauses in Bills or LADING 99-I42 (I962). 
the transaction involves contacts exclusively with a country whose law is violatedthe strongest case possible-a court sitting in another country is ordinarily free to disregard that law and its policies. ${ }^{48}$ A different result is reached only where international obligations imposed by bilateral or multilateral conventions compel the application of a definite foreign law or where, in the absence of such obligation, giving effect to the applicable law would constitute a violation of the forum's own policy. Thus, it has been suggested with good reason that "evasion" of mandatory rules adopted in international conventions for uniform maritime law should be considered as contrary to the public policy of all contracting states. ${ }^{49}$

\section{II}

\section{A Survey of the Progress of Unification}

\section{A. Collision}

The liability of shipowners in case of collision between vessels was one of the first subjects considered by the Comité Maritime International for possible international unification. ${ }^{50}$ There was indeed a hopeless conflict of national laws with respect to the principles of liability at the end of the nineteenth century, as illustrated by a celebrated case which, on the same facts, gave rise to substantially different determinations in three different countries. ${ }^{51}$ In the hope that it was putting an end to this unacceptable situation, the Brussels Diplomatic Conference adopted on September 23, I910, the International Convention for the Unification of Certain Rules of Law with Respect to Collisions Between Vessels.

The rgro Convention establishes a number of fundamental principles and leaves room for national implementation, particularly with respect to matters of procedure which are hardly touched upon by the uniform rules. Under the Convention, liability for collision is predicated exclusively on fault (articles 2 and 3). If two or more vessels are at fault, the liability of each vessel is proportioned to the degree of their respective faults, without joint and several liability to third persons for property damage. Thus, if a vessel is one-third at fault, it will be liable for only one-third of the damage to the other vessel or its cargo, or to the property of the crews, passengers, or other persons aboard either vessel. But in respect of damages caused by death or personal injuries, the vessels at fault are jointly and severally liable to third persons, with right of contribution among joint tortfeasors (article 4). The provisions of this Convention do not affect in any way the law in force in each country with regard to the limitation of the liability of the shipowner, nor

\footnotetext{
${ }^{4}$ See Neumayer, Autonomie de la volonté et dispositions impératives en droit international privé des obligations, [1957] Rev. CR. Dr. INT'L Pr. 579, 601.

${ }^{40}$ See 2 Ernst Rabel, Conflict of Laws: A Comparative Study 429 (2d ed., Drobnig I96o).

${ }^{10}$ See Comment, The Difficult Quest for a Uniform Maritime Law: Failure of the Brussels Conventions to Achieve International Agreement on Collision Liability, Liens, and Mortgages, 64 YALE L.J. 878, 879 (I955).

${ }^{52}$ See Franck, A New Law for the Seas, 42 L.Q. REv. 25 (1926).
} 
do they alter obligations arising from contracts of carriage or from any other contracts (article io).

The Convention applies to collisions between sea-going vessels or between seagoing vessels and vessels of inland navigation, in whatever waters the collision takes place (article I). Further, the Convention applies when all the vessels concerned in any action belong to contracting states, and in any other cases for which the national laws may provide. But when an interested person is a national of a noncontracting state, the convention may be applied by contracting states on the condition of reciprocity; and when all interested persons belong to the same state as the court trying the case, the provisions of the national law are governing rather than those of the Convention (article I2). The Convention does not apply to warships or to government ships appropriated exclusively to a public service (article II).

A large number of countries have ratified or adhered to this Convention. ${ }^{52}$ The United States, however, though a signatory country, has failed to ratify the Convention mainly due to the opposition of American cargo interests to the principle of proportional liability. ${ }^{53}$ Under American law, if both vessels are in any degree of fault, the cargo recovers one hundred per cent from the non-carrier, even if that vessel's fault is slight. ${ }^{54}$ American shipowners, who greeted the principles of the Convention with enthusiasm, sought in the past to bring national practice in line with the Convention by the use of contractual "both-to-blame" clauses. ${ }^{\text {b5 }}$ Their efforts did not meet with success, however, because the United States Supreme Court, when the occasion arose, declared such clauses to be invalid. ${ }^{\text {wo }}$

The failure of the United States to adhere to the law of collision liability followed by practically all other maritime nations is to be regretted. The disparity of collision liability here and abroad, combined with varying rules with respect to the limitation of the shipowner's liability, has encouraged forum shopping and has to some extent prevented the achievement of a much desired uniformity in this area. ${ }^{57}$

While the rgro Convention succeeded in unifying a number of substantive rules of law concerning liability for collision, it left open the involved questions of jurisdiction and procedure in matters of collision. Yet, it is precisely in this area that

${ }^{2}$ See list, Nagendra Singh, International Conventions of Merchant Shipping ro50.5i (1963).

${ }^{53}$ See Comment, The Difficult Quest for a Uniform Maritime Law: Failure of the Brtussels Conventions to Achieve International Agreement on Collision Liability, Liens, and Mortgages, 64 YALE L.J. 878, 88x (1955).

${ }^{6}$ See Grant Gilmore \& Charzes L. Black, Jr., Admiralty 438, I52-55 (1957); John W. Grifpin, The AMERICAN LAw of Colzistons 509-12 (1949).

${ }^{55}$ These clauses provided, typically, that cargo owners who recovered damages in full from the noncarrying vessel would indemnify the carrying vessel for amounts contributed on account of damages to its own cargo in the adjustment of losses between the vessels at fault. The purpose of these clauses, therefore, was to insulate the carrier from indirect liability to his own cargo and to secure, in collision cases, the immunity to which the carrier was directly entitled under the Carriage of Goods by Sea Act. See Grant Gilmore \& Charles L. Black, Jr., Admiralty I52-55 (1957).

${ }^{50}$ See United States v. Atlantic Mutual Ins. Co., 343 U.S. 236 (1952).

"zi See Gilmore \& Biack, Admiralty 439 (1957). 
procedural and substantive rules are closely interrelated and persisting conflicts of procedural laws minimize the desirable uniformity. For years, therefore, the Comité Maritime International had been working for the adoption of a Convention dealing with procedural matters; and on May 10, 1952, the Brussels Diplomatic Conference adopted, with substantial unanimity, the International Convention on Certain Rules Concerning Civil Jurisdiction in Matters of Collision. ${ }^{58}$

Under the $x 952$ Convention, actions in matters of collision may be brought only before courts sitting at the habitual place of residence or business of the defendant, where the vessel has been or could have been arrested, and at the locus delicti, if the collision took place in ports or in inland waters (article $x$ ). These jurisdictional rules do not prejudice the validity of jurisdictional clauses in contractual agreements or the right of the parties to submit to arbitration (article 2). Counterclaims may be brought before the court in which the principal action is pending. If there are several claimants, any claimant may bring his action before the court previously seized of an action against the same party arising out of the same collision. And, if a court is already seized of an action by reasons of the provisions of the Convention, the same court may exercise jurisdiction under its national laws in further actions arising under the same incident (article 3). The Convention applies not only to actual collisions but also to incidents of faulty navigation which give rise to either property damage or personal injuries (article 4).

The Convention is applicable when all vessels involved in a collision fly flags of the contracting states. The contracting states, however, are free to apply the Convention in favor of nationals of non-contracting states on the condition of reciprocity; and, if nationals of a single contracting state are involved in litigation before its courts, the provisions of the national law rather than those of the Convention apply (article 8). The Convention does not affect the law applicable to collisions of warships or government vessels appropriated exclusively to a public service (article 5), to claims arising from contracts (article 6), or to cases governed by the Rhine Navigation Convention of October 17, r868 (article 7). Finally, provision is made for compulsory arbitration of disputes among contracting states with respect to the interpretation or application of the Convention, without prejudice to obligation for submission to the jurisdiction of the International Court of Justice (article 9).

The Convention has been ratified by a number of states, including Great Britain. ${ }^{69}$ The United States has neither signed nor adhered to this Convention.

${ }^{58}$ Demeur, La Convention internationale du ro mai 1952 sur la compétence civile en matière d'abordage, [1953] Revue de Droit International et de Droit Compare [hereinafter cited as Rev. Dr. INT't ET DR. CoMp.] 25 (1953); Lilar \& Bosch, The International Brussels Conventions of May 10, 1952, for the Unification of Certain Rules Relating to Penal and Civil Jurisdiction in Matters of Collision and Arrest of Vessels, [1952] L'UnIfication dU DROIT 341, 357; Ripert, Les Conventions de Bruxelles du 10 mai I952 stur l'unification du droit maritime, [1952] D.M.F. 343, 348.

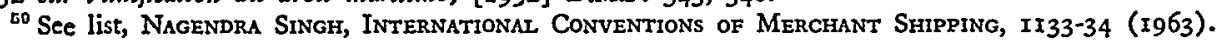


Acts of negligent navigation giving rise to collisions at sea are punishable offenses under the law of all maritime nations. ${ }^{60}$ Jurisdiction in this matter may be exercised by any court competent to give judgment under its own national law. This principle was affirmed by the Permanent Court of International Justice in the celebrated Lotus $^{61}$ case which held that the prosecution of officers of a foreign vessel involved in a collision with a national vessel on the high seas is not contrary to international law. Following this decision, the International Association of Officers of the Merchant Marine and the International Labor Organization became active pressing for an international agreement on matters of criminal and disciplinary jurisdiction. The Comité Maritime International prepared a Draft Convention, and the Brussels Diplomatic Conference adopted on May 10, 1952, the International Convention for the Unification of Certain Rules Relating to Penal Jurisdiction in Matters of Collision or Other Incidents of Navigation. ${ }^{62}$

Under this Convention, criminal or disciplinary proceedings against the master or any other person in the service of a sea-going vessel involved in a collision or any other incident of navigation may be instituted before the judicial or administrative authorities of the state of the flag (article I). It is expressly provided that neither arrest nor detention of the vessel may be ordered by any authorities other than those of the flag of the ship (article 2). However, states whose nationals are involved in collisions or other incidents of navigation aboard foreign ships may institute proceedings against these persons (article 3). The Convention does not apply to collisions or other incidents of navigation taking place in ports or inland waters, and further, reservations may be made by the contracting states as to the application of the convention to occurrences in territorial waters (article 4). The contracting states assume the obligation to submit disputes concerning interpretation or application of the Convention to arbitration, without prejudice to any obligation to submit disputes to the International Court of Justice (article 5).

The Convention has already been ratified by a considerable number of nations, including Great Britain. ${ }^{63}$ It has neither been signed nor adhered to by the United States.

\section{B. Salvage and Maritime Assistance}

In spite of frequent assertions that the law of salvage and assistance at sea ${ }^{04}$ formed part of the "jus gentium," ${ }^{\prime 65}$ this law was anything but uniform in various

${ }^{\circ 0}$ See Lilar \& Bosch, supra note 58, at $35 \mathrm{x}$.

e1 The S.S. "Lotus" (France v. Turkey), P.C.I.J., ser. A, No. to (1927).

${ }^{62}$ Lilar \& Bosch, The International Brussels Conventions of May 10, 1952, for the Unification of Certain Rules Relating to Penal and Civil Jurisdiction in Matters of Collision and Arrest of Vessels, [r952] L'Unification dU Drort 341, 348; Ripert, Les Conventions du ro mai r952 sur l'unification du droit maritime, [1952] D.M.F. 343, 344.

${ }^{3}$ See list, Nagendra Singh, Internationaz Conventions op Merchant Shipping ir36 (1963).

of For the distinction between salvage and assistance under continental legislation prior to the adoption of the I9ro Convention, see 3 Georges RIPERT, Drolt Maritime I2I (4th ed. 1953).

${ }^{\circ 5}$ Gilmore \& Black, ADMiraity 444 (1957). 
countries at the end of the nineteenth century. Not only was there no universally recognized obligation to furnish assistance at sea, but the rights and obligations of the salvor and of the recipient of the services also differed from country to country. ${ }^{68}$ Since the perils of the sea are not confined by national boundaries, international uniformity in this area is particularly desirable. It is understandable, therefore, that one of the earliest projects of the Comité Maritime International was the adoption of an International Convention for the Unification of Certain Rules of Law relating to Salvage and Assistance at Sea (Brussels, Sept. 23, I910).

The rgro Convention establishes the obligation of every master to render assistance to everybody, even an enemy, found at sea in danger of being lost, so far as he can do so without serious danger to his vessel, the crew, and the passengers (article II) ${ }^{67}$ This obligation, whose breach does not result in liability for the shipowner, is expressly limited to assistance due to persons. The salvage of property under the Convention is, as it should be, a voluntary matter for the salvor.

The Convention provides generally that every act of assistance or salvage which has had a useful result gives rise to a right for equitable remuneration not in excess of the value of the property salved (article 2). Remuneration is due even if the services have been rendered by or to vessels of the same owner (article 5), but, if the assistance has been rendered by a tug to vessels in tow, remuneration is due only for exceptional services (article 4). No remuneration is due for the saving of life, but contrary provisions of national laws are not affected by the Convention (article 9). Further, no remuneration is due to persons who have taken part in salvage operations contrary to an express and reasonable prohibition of the recipient of the services (article 3). The amount of remuneration and its apportionment among salvors is fixed by agreement of the parties, and in the absence of agreement, by the court. The apportionment of the remuneration among the owner, master, and other persons in the service of the salving vessel, however, is governed by the law of the flag of that vessel rather than the Convention (article 6). Agreements entered at the moment and under the influence of danger as well as agreements vitiated by concealment of facts or fraud may be annulled or modified by the court (article 7) in accordance with equitable considerations (article 8).

The Convention applies to assistance and salvage of sea-going vessels in danger and also to services of the same nature rendered by sea-going vessels to vessels of inland navigation or vice versa (article I). Further, the Convention applies when either the salving vessel or the recipient of the services belongs to a contracting state, as well as in any other case for which the national laws may provide. When an interested person is a citizen of a non-contracting state the provisions of the convention may be applicable on condition of reciprocity; and when all interested

${ }^{\circ 0}$ See 3 Georges Ripert, Droit Maritime I26 (4th ed. I953).

${ }^{67}$ Article 8 of the rgro Collision Convention establishes, correspondingly, the obligation of the master of each of the vessels involved in collision to render assistance to the other vessel, her crew and her passengers, so far as he can do so without serious danger to his vessel, her crew, and her passengers. 
persons belong to the same contracting state application of the convention is excluded (article 15). The Convention does not apply to ships of war and government vessels serving exclusively a public purpose (article 14 ) ${ }^{68}$

A large number of countries have ratified or adhered to the Convention, including the United States. ${ }^{69}$ Further, most countries have adopted the principles of the Convention as their domestic law. ${ }^{70}$ In the United States, the Convention was taken as codifying American salvage law with a few minor exceptions as to which legislative amendment occurred by the Salvage Act of 1912. Except for the statutory changes, the Convention has played little part in the development of American salvage law and has almost never been construed, discussed, or cited. ${ }^{71}$

\section{Contracts of Carriage}

Already by the end of the past century, divergencies in the regulation of the seacarriers' liability under contracts of affreightment evidenced by bills of lading had attracted attention and had caused concern. The most spectacular conflict in that regard involved the question of validity of "negligence" clauses, namely clauses designed to exonerate the carrier from liability for his or his servants' negligence in connection with damage to the cargo. ${ }^{72}$

In some countries cargo interests had prevailed and strict liability had been imposed on carriers for loss or damage to the goods carried; in other countries hull interests had prevailed, and the carriers enjoyed an almost unlimited freedom of contracting. Moreover, the national policy favoring the shipper or the carrier was frequently extended in the field of conflicts of law by the adoption of choice-of-law rules designed to safeguard application of national law to bills of lading involving international contacts. Thus, due to a variety of substantive standards and conflicts rules, a negligence clause inserted in an international bill of lading could be valid in one country and invalid in another, and the liability of the carrier could differ with the fortuitous or selected forum. As a result, security in international transactions was minimized, the negotiability of bills of lading was imperiled, and world trade was seriously hampered. ${ }^{73}$

The United States, having first succeeded in reaching a compromise between the conflicting interests of shippers and carriers in its Harter Act, ${ }^{74}{ }^{1893}$, took the lead in urging uniform international regulation of the sea-carriers' liabilities. After several

\footnotetext{
${ }^{68}$ See Le Poittevin, Quse signifie l'art. 14 de la Convention de Bruxelles du 23 septembre 1910 pour l'unification de certaines règles en matière d'assistance et de sauvetage maritimes?, [1955] Annunar Franchas de Droit Internationaz [hereinafter cited as ANN. Fr. DR. INT'L] 183 .

${ }^{60}$ See 37 Stat. 1658 (1913) (ratification); U.S. Salvage Act of 1912, 37 Stat. 242 (1912), 46 U.S.C.A. $\$ \$ 727-73$ (1958). See also list, Nagendra Singh, International Conventions op Merchant SHIPPING III5-I6 (I963).

${ }^{70}$ See 3 Georges Ripert, Drom Maritme 107-08 (4th ed. I953).

72 See GHMORE \& Black, ADMIRALTY 445 (I957).

${ }^{72}$ See A. N. Yiannopoulos, Negligence Clauses in Ocean Bills of Ladinc 4-9 (1962).

73 See Arnozd W. Knauth, The American Law of Ocean Bills of Ladino i20 (4th ed. 1953 ).

74 27 Stat. 445 (1893).
} 
decades of preparatory works and back-stage negotiations, the International Law Association adopted at its Hague meeting of I92I a body of rules known as Hague Rules, 1921. The following year, the Hague Rules were molded by the Comité Maritime International into a Draft Convention which was subsequently submitted by the Belgian Government to the Fifth Diplomatic Conference on Maritime Law (Brussels, October 1922). The original text of the Hague Rules was extensively discussed by the Conference in a number of sessions and the movement for uniformity culminated in the signing, on August 25, I924, of the International Convention for the Unification of Certain Rules of Law Relating to Bills of Lading.

Like all other Brussels Conventions, the Bills of Lading Convention has not been conceived as a comprehensive and self-sufficient code regulating the carriage of goods by sea; it has been intended merely to unify "certain rules of law" relating to bills of lading, and only with regard to damages occurring between the time of loading and discharge to hull cargo other than live animals (article $I(b)(e)(c)$ ). All bills of lading covered by the Convention are subject to certain standard clauses defining the risks assumed by the carrier, which are absolute and cannot be altered by contrary agreement, and the immunities the carrier can enjoy, unless the parties agree otherwise. In general, clauses relieving the carrier from liability for negligence in loading, handling, stowing, keeping, carrying, and discharging goods, or clauses which diminish his obligation of diligence to furnish a seaworthy vessel are declared null and void (article 3 (I)(2)(9)). The carrier, however, is relieved from liability for negligence in "navigation or in the management" of the vessel and from the absolute warranty of seaworthiness (article 4 (I)(2)(a)). According to its article 10, the Convention should apply to all bills of lading issued in any of the contracting states.

It was hoped that, by balancing the conflicting policies of maritime nations and the interests of shippers and carriers, the Brussels Convention would standardize the liabilities of the carriers on the international level. And it was expected that as to matters regulated by the Convention, the results of possible litigation would be the same in the courts of any of the contracting states. Unfortunately, the optimism which prevailed at the time the Convention was signed proved to some extent illusory, although most of the maritime nations have ratified or adhered to the Convention, and others without formally adhering have enacted domestic legislation incorporating the rules agreed upon in Brussels. ${ }^{75}$ In spite of this substantial formal uniformity of national legislation, conflicts problems arising from the determination of the carriers' liability and the validity of negligence clauses in bills of lading still persist. The very text of the Convention, as finally adopted, left the door open for subsequent deviations to the prejudice of the desired uniformity ${ }^{76}$

\footnotetext{
${ }^{75}$ See list, Nagendra Singe, International Conventions of Merchant Shipping I086-87 (1963).

70 See Protocol of Signature: "The High Contracting Parties may give effect to this Convention either by giving it the force of law or by including in their national legislation in a form appropriate to that legislation the rules adopted under this Convention."
} 
The rules were adopted in the various countries with modifications and textual variations, and under various legislative methods. ${ }^{77}$ Hence, conflicts among texts incorporating the uniform rules an conflicting interpreations are not infrequent. ${ }^{78}$ $\therefore$ Moreover, the area of application of the uniform rules and the choice of law rules applied to bills of lading outside the scope of these rules (as enacted in the forum) differ from country to country. These divergences in substantive legislation and choice-of-law rules, to the extent that they still persist, result in confusion and uncertainty. Depending on the place of litigation, the same bill of lading may or may not be subject to the uniform rules, even where the forum is in a contracting state and the bill of lading involves contacts with another contracting state. As in the past, the liabilities of the carrier may differ with the forum in some cases, and a negligence clause may be valid in one country and invalid in another country contrary to both the letter and the spirit of the Convention. Quite happily, however, the unsatisfactory state of the law has not gravely prejudiced uniformity-in-fact, as all major shipping companies have incorporated in their bills of lading the rules of the Convention. ${ }^{79}$

In its 1963 Stockholm Conference the Comite Maritime International adopted, for the purpose of furthering uniformity in this area, a number of proposed amendments to the Bills of Lading Convention in the form of a "Draft Protocol or Convention," ${ }^{30}$ which in due course will be submitted to the Diplomatic Conference. Most of these amendments concern the substance of the uniform rules, particularly in the light of their interpretation by British courts. ${ }^{81}$ One proposed amendment concerns the area of application of the uniform rules which are made applicable to both inward and outward shipments to or from any state which subscribes to the Convention. ${ }^{82}$

While the Bill of Lading Convention succeeded in establishing a degree of international uniformity with respect to the carriage of goods, the carriage of passengers and their luggage by sea-going vessels until recently remained subject

\footnotetext{
${ }^{77}$ See, in general, Demetrios J. Markianos, Die Übernahme der Hanger Regel in die nationaten GeSETZE ÜBER die VeRFrachterhaftuNg (I960).

${ }^{78}$ See, e.g., William E. Astle, Shipowners' Cargo Liabilities and Immunities io6 (195I); Graveson, Bills of Lading and the Unification of Maritime Law in the English Courts, in Summer Schoot of University of Michigan, Conflict of Laws and International Contracts 57, 6i-63 (1949); of. Comment, Ocean Bills of Lading and Some Problems of Confict of Latus, 58 Colum. L. REv. 212 (1958).

${ }^{70}$ See Stödter, Zur Statutenkollision im Seefrachtvetrag, in LIBER AMicorum or Congratulations to Algot Bagge 220. (I955).

${ }^{80}$ See Legendre \& Lureau, La Conférence de Stockholm du Comité Maritime International, [1964] D.M.F. $387,388-94$.

${ }^{81}$ See Grönfors, Why not Independent Contractors?, [ ${ }^{96} 4$ ] Journal of Business Law [hereinafter cited as J.B.L.] 25; Colinvaux, Revision of the Hague Rules Relating to Bills of Lading, [1963] J.B.L. 341.

${ }^{22}$ The proposed new article ro reads: "The provisions of this Convention shall apply to every bill of lading for carriage of goods from one state to another, under which bills of lading the port of loading, of discharge or one of the optional ports of discharge, is situated in a Contracting State, whatever may be the nationality of the ship. the carrier, the shipper, the consignee or any other interested person."
} 
to various national laws with conflicting areas of application. It was thus only in 196r that the Brussels Diplomatic Conference acted favorably on the recommendation of the Comite Maritime International and adopted the International Convention for the Unification of Certain Rules Relating to the Carriage of Passengers by Sea ${ }^{83}$

The 196r Convention establishes the obligation of any carrier ${ }^{84}$ to exercise due diligence to furnish a seaworthy and properly manned ship and to secure, in all respects, the safety of passengers (article 3 ). The carrier is liable for damage suffered as a result of the death of, or personal injuries to, passengers in the course of the carriage through his or her servants' negligence within the scope of their employment. Generally, the claimant has the burden of proof of negligence, but in cases of shipwreck, collision, stranding, explosion, or fire, the fault of the carrier is presumed unless the contrary is proved (article 4). If the carrier proves that the passenger was contributorily negligent, the carrier may be partially or wholly exonerated: in accordance with the lex fori (article 5). The liability of the carrier for death or personal injuries to a passenger is limited to 250,000 gold francs, convertible into national currencies. National laws, however, or contractual agreements may fix a higher per capita limit of liability (article 6). Limitation of liability cannot be invoked with respect to damages resulting from intentional faults or recklessness (article 7). Further, the Convention does not affect provisions relating to the limitation of the shipowners' liability found in other conventions or in national laws (article 8). Contractual clauses purporting to diminish the liability of the carrier either directly, or indirectly by means of jurisdictional clauses or arbitration agreements, are declared void (article 9). Other provisions deal with parties plaintiff and parties defendant, the requirement of notice, and the applicable period of limitations (articles $\mathrm{xO}-\mathrm{I} 2$ ).

The Convention applies to any international carriage by sea-going vessels under contracts of carriage other than charterparties (article $x(b)(d)$ ), if either the ship flies the flag of a contracting state or if, according to the contract of carriage; either the place of destination or the place of departure is in a contracting state (article 2). Further, the Convention applies to commercial carriage undertaken by states or public authorities (article 13 ). The Convention does not affect the provisions of any national law or international convention which may govern liability for nuclear damage (article I4). No state has as yet ratified or adhered to this Convention. ${ }^{85}$ It is to be hoped that maritime nations will soon act favorably in the interest of the welfare of passengers, who at present enjoy less protection with respect to claims for damages resulting from the negligence of the carrier than do goods carried in international commerce.

\footnotetext{
${ }^{83}$ See Legendre, La Conférence Diplomatique de Bruxelles de 1961, [x961] D.M.F. 3872 390-92. For previous drafts, see Hennebicq, The Tenth Session of the Diplomatic Conference on Maritime Law (Brissels, 1957), [1957] L'Unfication Du Droir 28I, $29 \mathrm{I}$.

81 "Carrier" under the Convention includes the shipowner, the charterer or the operator of the ship (article $\mathrm{r}(\mathrm{a})$ ).

${ }^{a}$ See Nagendra Singh, International Conventions of Merchant Shipping io7i (1963).
} 
The 196I Passenger Convention does not touch at all the controversial problem of the liability of the carrier for damage to passengers' luggage. In its 1963 Stockholm meeting, however, the Comité Maritime International voted favorably on a draft International Convention for the Unification of Certain Rules Relating to Carriage of Passenger Luggage by Sea. ${ }^{86}$ In its form and substantive provisions, this draft rather closely follows the $196 \mathrm{I}$ Passengers Convention, though solutions have also been borrowed from the r924 Bill of Lading Convention. The Luggage Convention establishes the obligation of the carrier to exercise due diligence to furnish a seaworthy vessel, bases liability on fault other than in the management or navigation of the vessel, relegates the issue of the effects of contributory negligence to the lex fori, provides for limitation of liability except in cases of intentional or reckless misconduct, and indicates the appropriate forum for the settlement of disputes. It is intended to apply to "international carriage," following with respect to the definition of this term the language of the Passengers Convention. Presumably, the draft will soon be considered by the Brussels Diplomatic Conference.

\section{Liability of Shipowners}

Limitation of the shipowners' liability has been termed a "fundamental principle"87 of maritime law. Indeed, all maritime nations follow some scheme of limitation of the shipowners' liability. ${ }^{88}$ In the United States, claims for property damage against a vessel are limited, in general, to the value of the ship after the occurrence. If the vessel is totally lost, the owner is liable only up to the extent of his interest in the freight then pending. ${ }^{89}$ For losses arising out of death or personal injuries, however, claimants are guaranteed recovery from a fund equal to $\$ 60$ per ton. ${ }^{90}$ In all cases limitation of liability is conditional on the absence of "privity or knowledge" 11 on the part of the owner. In Great Britain, liability was limited until $195^{8}$ to $£^{8}$ per ton for property damage and $£_{15}$ per ton for death and personal injuries.92 Continental countries have traditionally followed the system of abandonment of ship and freight to creditors, whether in kind or in the form of a fund representing their value. ${ }^{33}$

The disparity of national legislation on such an important matter has prompted

${ }^{88}$ See Legendre \& Lureau, La Conférence de Stockholm du Comité Maritime International, [1964] D.M.F. $387,397-400$.

${ }^{87}$ See 2 Georges Ripert, Droit Maritime 139 (4th ed. 1952).

${ }^{88}$ For concise statement of the general principles of American and foreign law, see DocuneEN ro6 of the Maritime Law Association of the United States, The History and Recent Status of Domestic and Foreign Laws Concerning Limitation of Shipowners' Liability (I935).

${ }^{80}$ See 46 U.S.C.A. $\$$ I83 (a) (I958); GilMore \& BLACK, ADMiralty 668 (1957).

${ }^{90}$ See Rev. Stat. $\$ 4283$ (I875), 46 U.S.C. $\$ 183$ (b) (1964).

${ }^{21} 7 d$. $\$ 183(\mathrm{a}),(\mathrm{e})$.

${ }^{82}$ See Merchant Shipping Act, $1894,57 \& 58$ Vict., c. 60, $\$ 503$. The act has been amended by the Liability of Shipowners and Others Act, 1958, $6 \& 7$ Eliz. 2, c. 62, to incorporate the provisions of the 1957 Limitation of Liability Convention. See text at note 96 infra; Robert Temperley, The Merchant Shipping Acts 800, 8 ro (Porges \& Thomas, 6th ed. 1963).

${ }^{93}$ See 2 Georges Ripert, Droit Maritime 142, 148 (4th ed. 1952). 
the International Law Association and the Comite Maritime International to undertake projects for the unification of the law in this field. ${ }^{94}$ After several decades of preparatory works, the movement for uniformity culminated in the International Convention for the Unification of Certain Rules Relating to the Limitation of Liability of Owners of Sea-going Vessels, signed at Brussels, on August 25, I924. This Convention sought to reconcile the conflicts among national legislation by giving an option to shipowners for limitation of their liability in certain enumerated instances either by abandoning the value of the ship and freight to claimants or by constituting a fund of specified amounts.

Under the Convention, the liability of the shipowner is generally limited to the value of the vessel, its freight, and accessories; but in specified instances the ship. owner may further limit his liability for property damage to a lesser amount of $£ 8$ per ton (article I). Freight is always fixed at ten per cent of the value of the ship at the commencement of the voyage (article 4). Claimants of damages for death or personal injuries have exclusively at their disposal an additional fund of $f_{8} 8$ per ton, and if they are not fully satisfied, they rank equally with other claimants in the distribution of the general fund (article 7). The various claims connected with a single accident rank with one another against the amount representing the extent of the owner's liability (article 6). The Convention specifies the time of valuation (article 3) and the method of calculation of tonnage (article II). While the monetary units referred to mean gold values, states have reserved the right to translate the sums in terms of their own monetary systems and to accord to the debtor the right to pay in national currency at the rate of exchange at the time of valuation (article 15). Limitation of liability is excluded with respect to obligations arising out of personal acts or faults of the shipowner and out of engagements of persons in the service of the vessel (article 2).

The Convention applies to sea-going vessels belonging to a contracting state and in all other cases provided for by national laws. A contracting state, however, is free not to apply the convention in favor of nationals of non-contracting states (article 12). By express provisions, the Convention does not apply to ships of war and government vessels serving exclusively a public purpose (article I3), nor does it affect matters of jurisdiction and procedure before national courts (article 14).

The 1924 Convention has enjoyed limited success, without the United States or Great Britain adhering to it. ${ }^{95}$ Giving in to pressure from the Anglo-American world, the Comite Maritime International prepared a new text which was promptly adopted by the Brussels Diplomatic Conference on October 10, $1957^{.96}$ The new

" Id. at 156-58. Ripert, La responsibilité des propriétaires de navires et l'unification internationale du droit maritime, [1954] D.M.F. 703.

${ }^{\circ 5}$ See Nagendra Singh, International Conventions of Merchant Shipping 1058 (1963).

${ }^{\circ 0}$ See Lureau, L'unité du droit maritime international et la Convention de Bruxelles de 1957 sur la limitation de responsabilité des propriétaires de navires, [1964] D.M.F. 259 (1964); Helm, Das Brüsseler Abkommen von 1957 äber die Beschränkung der Reederhaftung und das deutsche Recht, 24 Rabels Z. 639 (1959); Ripert, La Conférence Diplomatique de Braxelles de 1957, [1957] D.M.F. 7rr. 
Limitation of Liability Convention, designed to replace the 1924 Convention, has been ratified by a number of nations but has not as yet entered into force. ${ }^{07}$

Under the complex scheme of the new Convention, the shipowner may limit his liability in respect to claims arising from a number of enumerated instances (exclusive of salvage, contribution in general average, and contracts for personal services), unless the occurrence giving rise to the claims has resulted from the actual fault or privity of the owner (article r). Subject to certain exceptions, the same right is accorded to the charterer, manager or operator of the ship, and to the servants of the owner (article 6). The lex fori determines who has the burden of proof of the owner's fault or privity (article $\mathrm{I}$, section 6). The limits of liability are set out in article 3. Where the occurrence has given rise to property damages only, the limit is $x, 000$ francs per ton. Where the occurrence has given rise to claims for death and personal injuries only, the limit is 3,roo francs per ton. Where it has given rise to both property damage and personal claims, the limit is still 3,100 francs, but the first 2,100 are appropriated exclusively to the payment of personal claims and the rest to claims for property damage, with unsatisfied claimants of the first category ranking equally with claimants of the second category in the distribution of the second portion of the fund. The fund must be constituted for each distinct occurrence (article 2). The franc is defined as a unit consisting of sixty-five and a half miligrams of gold millesimal finess nine hundred, convertible into national currencies (article 3, section 6). The details of constitution and distribution of the fund and all rules of procedure are matters governed by the national law of the contracting states (article 4).

The Convention applies to sea-going ships (article $\mathrm{r}$, section $\mathrm{x}$ ) but the contracting states have reserved the right to decide what other classes of ships will be treated in the same manner (article 8). The Convention further applies whenever a person entitled to claim limitation seeks to limit his liability or to procure release of property before the courts of a contracting state. The contracting states, however, are free not to apply the Convention in favor of a non-contracting state, a person who has his residence or principal place of business in a non-contracting state, or a ship which flies the flag of a non-contracting state (article 7). The Convention will come into force after its ratification by at least ten states, five of which must have at least a tonnage of one million gross tons (article $\mathrm{r}$ ), and will then replace the $x 924$ Convention (article r6).

Whether this new Convention will meet with greater success than its predecessor is a matter of conjecture. Doubts have already been voiced with respect to the soundness of some of the new substantive provisions. ${ }^{98}$

The two Conventions on Limitation of Liability have been based on facts and

\footnotetext{
- ${ }^{27}$ See Nagendra Singh, International Conventions of Merchant Shipping 1064 (1963).

${ }^{98}$ See Lureau, L'unité du droit maritime international et la Convention de Bruxelles de 1957 sur la limitation de responsabilité des propriétaires de navires, [1964] D.M.F. 259.
} 
considerations pertinent to "normal" ships. Problems of liability for damage resulting from the operation of atom-powered vessels have been dealt with in the International Convention on the Liability of Operators of Nuclear Ships, signed at Brussels on May 25, $1962 . .^{99}$

This Convention imposes absolute liability on the operator of a nuclear ship for any damage caused by a nuclear incident involving the nuclear fuel of, or radioactive products or waste in, the ship (article 2 ). This liability is limited to 1,500 million convertible gold francs in respect of any nuclear incident, even if caused by the fault or privity of the operator (article 3). The Convention further provides for limitation of actions (article 5), jurisdiction of national courts (article ro), satisfaction of judgments (article II), and settlement of disputes between contracting states either by arbitration or submission to the International Court of Justice (article 20). The contracting states have reserved the right to deny access to their waters and harbors by any nuclear ship (article I7). The Convention applies to nuclear damage occurring in any part of the world and involving the nuclear fuel or radioactive products or waste produced in a nuclear ship flying the flag of a contracting state (article I3). This Convention has not been signed by the United States or the U.S.S.R., the two countries which possess nuclear vessels. Nor has it been ratified or adhered to by any other nation. ${ }^{100}$ It may be expected, however, that the Convention will serve a useful purpose as a model for domestic legislation. ${ }^{101}$

\section{E. Maritime Liens and Mortgages}

In spite of its great commercial importance, the matter of maritime liens and mortgages is characterized by a high degree of international uncertainty. ${ }^{102}$ National laws differ widely with respect to the creation and enforcement of liens and mortgages; and rights of claimants, whether arising from contractual or delictual obligations, or from strictly speaking security transactions, may ordinarily be determined at any port in which the vessel calls. As a result, a claimant may have his claim substantially satisfied or entirely disregarded, depending upon the jurisdiction in which the vessel is seized and sold. It was aptly observed, therefore, several decades ago that "nothing short of . . . an international convention will suffice to iron out the variables and uncertainties which are bound to arise in respect to so thoroughly ambulatory a thing as a ship."103

${ }^{00}$ See Legendre, La Conférence Diplomatique de Bruxelles de 1962, [I962] D.M.F. 575.

${ }^{200}$ See Nagendra Singh, Internationat Conventions of Merchint Shipping io79 (I963).

${ }^{101}$ See Legendre, La Conférence Diplomatique de Bruxelles de 1962, [1962] D.M.F. 575, 578.

${ }^{102}$ See 2 Grorges Ripert, Droit Maritime 20-26 (4th ed. I952); Comment, The Difficult Quest for a Uniform Maritime Law: Failure of the Brussels Conventions to Achieve International Agreement on Collision Liability, Liens, and Mortgages, 64 YALE L.J. 878, 893-903 (1955).

${ }^{103}$ Gustavus H. Rosinson, Handboox of Admiralty Law 435 n,226 (I939). See also Griffith Price, Maritme Liens 206 (I940); Lord \& Glenn, The Foreign Ship Mortgoige, 56 Yale L.J. 973 (1947). 
In keeping with this objective, the Comite Maritime International drafted, and the Brussels Diplomatic Conference adopted, the International Convention for the Unification of Certain Rules of Law Relating to Maritime Liens and Mortgages (Brussels, April ro, I926). ${ }^{104}$ The purpose of this Convention was to establish a standard list of liens and to fix their priorities, so that interests in vessels might become predictable, and the ship mortgage, an effective form of security. It was further hoped that by reducing the number of liens and by securing to mortgage creditors a share in the proceeds if the vessel were sold in a foreign country, the credit of shipowners would be greatly strengthened.

The Convention provides that mortgages, hypothecations, and "other similar charges upon vessels," duly created under the law of a contracting state to which the vessel belongs, and registered in a public register, shall be regarded as valid and shall be respected in all other contracting states (article $\mathrm{x}$ ). The Convention further determines the circumstances which give rise to maritime liens on the vessel and its accessories (article 2), as specifically defined (article 4). Mortgages and hypothecations rank immediately after the authorized liens. National laws may grant additional liens without affecting the ranking of mortgages and hypothecations (article 3). Other provisions establish the priorities among liens (articles 5 and 6), secure the enforcement of liens into whatever hands the vessel may pass (article 8), and indicate the circumstances under which liens are extinguished (article 9). The provisions of the Convention are applicable to vessels which are under the management of a person other than the owner, unless the owner has been dispossessed by an illegal act or the claimant is not bona fide (article 13).

The Convention applies in cases involving vessels which belong to a contracting state as well as in all other cases provided for by national laws. But the contracting states are free not to apply the Convention in favor of nationals of a non-contracting state (article 14). The Convention does not apply to warships or to government vessels exclusively serving a public purpose (article 15 ). It does not in any way affect the jurisdiction of courts or procedural rules in force in the contracting states (article 16 ).

The Convention has had limited success. ${ }^{105}$ Neither Great Britain nor the United States have adhered to it. Since, however, the United States Ship Mortgage Act, r922, and corresponding British legislation conform essentially with the principles of the Convention, the lack of international uniformity is much more apparent in respect of maritime liens rather than mortgages. ${ }^{108}$ It is expected that in its 1965

\footnotetext{
104 For an effort at reconciliation of the provisions of this Convention with those of the I957 Limitation of Liability Convention, see Muller, Obligation restreinte ou responsibilite limitke, [1964] D.M.F. I95.

${ }^{10 s}$ See list of ratifications and adherences, Nagendra Singh, International Conventions on Merchant SHIPPING 1092 (1963).

${ }^{108}$ See Comment, The Difficult Quest for a Uniform Maritime Law: Failure of the Brussels Conventions to Achieve International Agreement on Collision Liability, Liens, and Morfgages, 64 YALE L.J. 878, 905 (I955). See also Gilmore \& BLACK, ADMIralty 568-662 (I957).
} 
New York meeting the Comité Maritime International will discuss projects for the revision of the 1926 Convention. ${ }^{107}$

The 1926 Convention has nothing to do with rights in ships under construction. However, in this era of internationalization of financial operations and of the ship construction industry in particular, the need for security of rights and expanded credit in respect of ships under construction is ever increasing. The Comité Maritime International therefore has adopted in its 1963 Stockholm meeting a draft Convention Relating to Registration of Rights in Respect of Ships Under Construction. ${ }^{108}$ The draft provides for the inscription, in a register controlled by the state, of rights in ships under construction in that country. It fixes the moment from which registration is possible; prohibits discriminatory practices against foreigners; establishes a system of priorities of rights in accordance with the time of, or demand for, registration; and most important, provides for the survival of registered rights on the finished vessel and in case of its transfer to a new flag. This draft, along with other drafts prepared by the Comité Maritime International, will soon be considered for possible adoption by the Brussels Diplomatic Conference.

\section{F. Arrest of Vessels}

The emergence of Socialist states in the period between the two world wars, and increased commercial operations by state-owned fleets throughout the world, gave rise to controversies concerning the immunity of government vessels. In an effort to solve these problems by international agreement, the Comite Maritime International drafted, and the Brussels Diplomatic Conference adopted, the International Convention for the Unification of Certain Rules Concerning the Immunity of State-owned Ships ${ }^{109}$ (Brussels, April ro, 1926).

According to this Convention, sea-going ships owned or operated by states, cargoes owned by them, and passengers carried, as well as the states themselves, are subject, in respect of claims arising from such operations, to the same rules of liability as those applicable to privately owned ships, cargoes, and equipment (article I). Further, the rules relating to jurisdiction, rights of action, and procedures are the same as in the case of merchant ships (article 2). The provisions of this Convention, however, do not apply to ships of war and, in general, to vessels appropriated exclusively to a public service of a non-commercial nature, as state yachts, patrol boats, and hospital ships. Nevertheless, claimants are given the right to proceed before the courts of the state that owns or operates such vessels in matters of collision, other accidents of navigation, salvage, general average, and claims for

${ }^{107}$ See Legendre \& Lureau, La Conférence de Stockholm du Comité Maritime International, [1964] D.M.F. 387 , 397. For other current projects of the Comité Maritime International, see Legendre, La Conférence d'Athènes du Comité Maritime International, [1962] D.M.F. 383 (1962).

${ }^{108}$ See Legendre \& Lureau, La Conférence de Stockholm du Comité Maritime International, [1964] D.M.F. $387,394-97$ (1964).

${ }^{100}$ See I Georges Ripert, Droit Marminge 691-98 (4th ed. 1950). 
supplies, repairs, or services to the ship (article 3). Jurisdiction in these matters is governed by the provisions of article 2. States are entitled to rely on all defenses and limitations of liability available to private shipowners (article 4). For purposes of securing discharge from seizure, the character of a vessel as non-commercial may be conclusively certified by any interested government (article 5 ).

The provisions of this Convention apply in proceedings before the courts of contracting states, though not necessarily in favor of non-contracting states or their nationals (article 6). In times of war, the rules pertaining to the arrest of vessels may be suspended by interested governments, without affecting thereby the right of individual claimants to bring the appropriate personal actions (article 7). The Convention has been supplemented by an Explanatory Protocol, signed on May 24, 1934. ${ }^{110}$ It has been ratified or adhered to by a large number of states, with the exception of Great Britain and the United States. ${ }^{111}$ In these two countries, however, domestic legislation has been enacted concerning proceedings against state-owned vessels. ${ }^{112}$

The 1926 Convention left intact the more general matter of the arrest of privately owned sea-going vessels. Yet, the arrest of ships is of utmost importance to shipowners and to all persons who participate in maritime ventures. The grounds and procedures of arrest vary widely from country to country, and the cleavage is even more apparent in the light of a comparison between continental and Anglo-American conceptions. ${ }^{113}$ The need for international uniformity in this field was early felt but disagreements as to the most suitable rules stood in the way for several decades. It was only on May 10, 1952, that the Brussels Diplomatic Conference was able to adopt the International Convention Relating to the Arrest of Sea-going Ships.114

This is a lengthy and involved Convention. Its article I defines "maritime claims" and other terms of art used in the following text. Article 2 provides that a ship flying the flag of one of the contracting states may be arrested only in respect of any of the enumerated maritime claims, without prejudice to the right of public authorities to arrest vessels in their jurisdiction under the national law. A claimant may arrest the ship which has given rise to his claim or, in indicated circumstances, other ships under the same ownership (article 3 , section I). If the charterer is responsible rather than the owner, the claimant may arrest ships in the ownership of the charterer (article 3, section 4). Arrest in any of the contracting states may be

110 See Nagendra Singh, International Conventions of Merchant Shipping 1124 (I963).

111 Id. at 1125 .

${ }^{112}$ See U.S. Suits in Admiralty Act, I920, 4 I Stat. 525-28, 46 U.S.C.A. $\$ \$ 74 \mathrm{r}-52$ (1958); GiLmore \& BlAcK, Admiraity 773-77 (I957); British Crown Proceedings Act, 1947, Io \&c II Gco. 6, c. 44; Robert Temperley (Ed.), Merchant Shmping Acts $x_{5} 60,1570$ (6th ed. 1963).

${ }^{113}$ Lilar \& Bosch, The International Brussels Conventions of May ro, 1952, for the Unification of Certain Rules Relating to Penal and Civil Jurivisdiction in Matters of Collision and Arrest of Vessels, [1952] L'Unification dU DroIr 34r, 365-83.

${ }_{114}$ See Ripert, Les Conventions de Bruxelles du mai 1952 sur l'unification du droit maritime, [I952] D.M.F. 343. 
made only once in respect of the same claim by the same claimant (article 3 , section 3). The availability of release on bond is subject to the provisions of article 5 . Liability for damages for improper arrest and all matters of procedure are expressly governed by the lex fori (article 6). The jurisdiction of courts to pass on the merits of the dispute involving the arrested vessel depends primarily on the lex fori. Quite apart from this jurisdiction under the national law, the Convention confers jurisdiction on the courts of the place of the arrest if the claimant has his habitual residence or principal place of business in that country, as well as in other specified circumstances (article 7).

The Convention applies to vessels flying the flag of one of the contracting states. Ships of non-contracting states may be arrested in accordance with the lex fori. Application of the Convention may be excluded as to any government or person who has no habitual residence or principal place of business in a contracting state. The Convention does not affect the law in force in a contracting state with respect to the arrest of vessels flying the flag of that state by persons having their habitual residence or principal place of business in that state. When the claim is asserted by a subrogee, this person is deemed to have the same habitual residence or principal place of business as the original claimant (article 8). It is stated expressly that the Convention does not create new substantive rights, nor does it establish new liens (article 9). The contracting states may reserve the right not to apply the Convention to certain specified claims (article Io). Disputes among contracting states concerning the interpretation or application of the Convention are subject to arbitration, without prejudice to the jurisdiction of the International Court of Justice (article II). The Convention has been ratified by a number of countries, including Great Britain. ${ }^{115}$ The United States has neither signed nor adhered to this Convention.

\section{G. Stowaways}

The handling and disposal of stowaways involves predominantly questions of public international law, administrative law, and constitutional law rather than private maritime law. Humanitarian considerations, however, have prompted the Comite Maritime International to draft, and the Brussels Diplomatic Conference to adopt on October 10, 1957, the International Convention Relating to Stowaways. ${ }^{118}$

After the definition of certain technical terms (article I), the Convention provides that the master of a ship bearing the flag of a contracting state may deliver a stowaway to the appropriate authorities at the first port in a contracting state if he considers that the stowaway will be dealt with in accordance with the provisions of

${ }^{125}$ See Nagendra Singh, International Conventrons of Merchant Shtpping irzo (1963).

${ }^{110}$ Hennebicq, The Tenth Session of the Diplomatic Conference on Maritime Law (Brussels, 1957), [1957] L'Unipication du Drort 28r, 287-9I; Ripert, La Conférence Diplomatique de Bruxelles de 1957, [1957] D.M.F. 7II, 715-16. 
the Convention. The appropriate authorities have, correspondingly, the obligation to receive the stowaway, if he is not under a previous individual order of deportation, and to deal with him in accordance with the Convention (article 2). The receiving authorities may return the stowaway to the state of his nationality, but if that state refuses to accept him, or if the stowaway possesses no nationality, they may return him to the port of embarkation or to the last port of call prior to his discovery, or to the country of the flag of the vessel aboard which the stowaway was found (article 3). In any case, the Convention does not affect the power or obligation of a state to grant asylum, and the receiving authorities as well as the master of the ship are directed to take into account the reasons put forward by the stowaway for not being disembarked or returned to ports mentioned in the Convention (articles 3 and 5). The costs of maintenance of the stowaway fall primarily on the shipowner, without prejudice to right of recovery from the state of the stowaway's nationality (article 4). The Convention, though ratified by a number of states, has not as yet entered into force. ${ }^{117}$

\section{Conclusion}

Almost seventy years ago, the founders of the Comite Maritime International envisioned a new uniform law of the seas extending to all incidents of maritime commerce. This certainly has not been accomplished. ${ }^{118}$ Not surprisingly, the quest for uniformity stumbled upon interests of states and private persons who felt that the added convenience of international uniformity would not constitute adequate compensation for the loss of economic advantages under existing, though conflicting, national laws. ${ }^{119}$ But if the various Brussels Conventions for the unification of maritime law have not been generally adopted, and conflicts of national laws with respect to important institutions of maritime law still persist, a major accomplishment of unification is with us to stay. The way has been paved, the work of unification goes on, and one may look with confidence to the future of the movement.

The various Brussels Conventions do not constitute a uniform maritime "code," as it has been rather optimistically suggested. ${ }^{120}$ But they have certainly greatly improved international trade relations and have succeeded in unifying "certain rules" of vital importance in a considerable number of countries. These uniform rules have been carefully drafted by international bodies of experts to serve the best interests of as

${ }^{117}$ See Nagendra Singh, International Conventions of Merchant Shipping 1067 (1963).

${ }^{118}$ See Harold C. GUtTeridge, Comparative Lat 149 (2d ed. 1949). The author regards the results of the movement for the unification of maritime law as "disappointing."

${ }^{110} \mathrm{Cf}$. RenE David, TraitE ÉLEMentaIRe de DROIT crvil comparE 184 (1950): "Unification implies sacrifices for everybody, but it would seem today that these sacrifices are indispensable in certain matters and that they may also carry compensation in the form of certain greater advantages from which everyone may profit." (Translation by this author.)

${ }^{120}$ See Chaveau, L'unification du droit maritime et le C.M.I., [1963] REv. TRIM, DR. Comm. 737, 745 (1963): "As a whole, the various conventions prepared by the Comite Maritime International contain the subject matter of a true small international code of maritime commerce." (Translation by this author.) 
many nations and as many private persons as possible, and they have been tested by experience. They may not always be the best rules possible from a theoretical point of view. But "a good rule with world-wide application is better than a better rule opposed by a number of nations." ${ }^{.121}$ One may expect, therefore, that the influence of the uniform rules will increase with time and that more nations will adopt them either by adherence to the various international conventions or by incorporation into their domestic legislation. Persisting divergence of national laws in vital areas of private maritime law should, indeed, be regarded as a "reproach to civilization."122 221 Grönfors, Why not Independent Contractors?, [1964] J.B.L. 25, 27.

${ }^{122}$ Wortley, Great Britain and the Movement for the Unification of Private Law since 1948, 32 TuL. L. REv. 54I (1958). 